\title{
Antistaphylococcal Activity of Selected Thiourea Derivatives
}

\author{
JOANNA STEFAŃSKA ${ }^{1 *}$, KAROLINA STĘPIEN ${ }^{1}$, ANNA BIELENICA², MAŁGORZATA WRZOSEK ${ }^{3}$ \\ and MARTA STRUGA ${ }^{3}$ \\ ${ }^{1}$ Department of Pharmaceutical Microbiology, Medical University of Warsaw, Poland \\ ${ }^{2}$ Chair and Department of Biochemistry, Medical University of Warsaw, Poland \\ ${ }^{3}$ Department of Pharmacogenomics, Faculty of Pharmacy, Medical University, Warsaw, Poland
}

Submitted 20 August 2015, revised 4 March 2016, accepted 8 March 2016

\begin{abstract}
Five of thiourea derivatives were prepared using as a starting compound 3-(trifluoromethyl)aniline, 4-chloro-3-nitroaniline, 1,3-thiazol2-amine, $2 \mathrm{H}$-1,2,3-triazol-4-amine and commercial isothiocyanates. All compounds were evaluated in vitro for antimicrobial activity. Derivatives 2 and 3 showed the highest inhibition against Gram-positive cocci (standard and hospital strains). The observed MIC values were in the range of $0.5-8 \mu \mathrm{g} / \mathrm{ml}$. The products effectively inhibited the formation of biofilms of methicillin-resistant and standard strains of Staphylococcus epidermidis. Inhibitory activity of thioureas 2 and 3 against Staphylococcus aureus topoisomerase IV was studied. The examined compounds were nongenotoxic.
\end{abstract}

Key word s: antistaphylococcal activity, anti-biofilm activity, genotoxicity, thiourea derivatives

\section{Introduction}

Staphylococci belong to the generally present, most important biofilm-formed pathogens and are responsible for a large number of serious nosocomial infections acquired after surgery or hospital (Leclercq, 2009; Agarwal et al., 2010). Methicillin resistant strains (both, coagulase-positive and coagulase-negative) often show resistance to many other antibiotics and chemotherapeutics, such as fluoroquinolones, macrolides, tetracyclines or glicopeptides. Staphylococcus aureus produces numerous virulence factors, e.g. hemolysin, exotoxin, enzymes (hyaluronidase, lipase, nuclease), surface proteins (that promote attachment to host proteins such as laminin and fibronectin) or enterotoxins (responsible for food poisoning) (Heczko et al., 2014). This bacterium can generate various types of infections, such as severe skin, subcutaneous tissue and bone infections, scalded skin syndrome, pneumonia, endocarditis, as well as can even cause severe sepsis (Chambers and DeLeo, 2009). Another, commonly present Staphylococcus species - Staphylococcus epidermidis - has the ability to produce extracellular mucous and is able to adhere to a variety of surfaces, e.g. joint implants, vascular lines or artificial heart valves (Arciola et al., 2005;
Mack et al., 2006). Colonization of such biomaterials or medical devices can generate difficult-to-combat local and systemic infections (Otto, 2008; 2009).

Bacterial biofilm constitutes a complex multidimensional structure formed by cells conglomerated with one another and with the base. It is composed of extracellular mucous produced by bacteria, proteins, polysaccharides, nucleic acids and water (Costerton et al., 1999). Biofilm can be formed by microorganisms belonging to one or different species and can develop on abiotic surfaces or on living tissues (Costerton et al., 1999; Donlan and Costerton, 2002).

The cells of micro-organisms living in the biofilm are, in comparison to planktonic forms, more resistant to antibiotics and chemotherapeutics used in pharmacotherapy (Høiby et al., 2010) as well as antiseptics or disinfectant (Bridier et al., 2011). This causes numerous therapeutic problems, especially in combating chronic infections. The formation of the biofilm by bacteria constitutes also an essential clinical problem linked to infections associated with medical devices, e.g. bone implants, catheters or vascular lines (Donlan, 2001; Maki et al., 2006).

Effective methods of fight down bacterial biofilm are still missing. It is extremely important to seek new

\footnotetext{
* Corresponding author: J. Stefańska, Department of Pharmaceutical Microbiology, Medical University of Warsaw, Warsaw, Poland; e-mail: jstefanska@wum.edu.pl
} 
compounds having antibacterial activity which would be effective in combating biofilm. They could be used, for instance, to cover surfaces of biomaterials or protective clothing, to prevent micro-organisms from settling on them and thus making it impossible for the difficultto-eradicate biofilm to form (Meng et al., 2013).

The thiourea fragment represents an important synthon which is responsible for numerous biological activities, such as antimicrobial (Struga et al., 2010; Vega-Pérez et al., 2012), antiviral (Ranise et al., 2003), anticancer (Saeed et al., 2010), cytotoxic (Vega-Pérez et al., 2012) and anti-inflammatory (Keche et al., 2012) properties. In many cases, antistaphylococcal potency of this class of compounds is the result of the type II topoisomerase inhibition, that includes topoisomerase IV and DNA gyrase (Basarab et al., 2013; Bielenica et al., 2015).

As a part of our research program of rapidly assemble novel bioactive compound we have synthesized five disubstituted thioureas. The compounds with various substituents at the thiourea moiety (aryl, heteroaryl and benzyl) were evaluated for their antimicrobial, as well as investigated as potential inhibitors on biofilm formation of Gram-positive pathogens. The mechanism of their action through topoisomerase IV inhibition was proved.

\section{Experimental}

\section{Materials and Methods}

Chemistry. 3-(Trifluoromethyl)aniline, 1,3-thiazol2-amine, 2H-1,2,3-triazol-4-amine, 4-chloro-3-nitroaniline were supplied from Alfa Aesar. Isothiocyanates were purchased from Alfa Aesar or Sigma Aldrich. Acetonitrile, chloroform and methanol were supplied from POCh (Polskie Odczynniki Chemiczne SA). All chemicals were of analytical grade and were used without any further purification. Before using, dry acetonitrile was kept in crown cap bottles over anhydrous phosphorus pentoxide (Carl Roth). The IR spectra were obtained on Perkin Elmer Spectrum 1000 spectrometer in $\mathrm{KBr}$ pellets. The NMR spectra were recorded on Varian VNMRS 300 Oxford NMR spectrometer, operating at $300 \mathrm{MHz}\left({ }^{1} \mathrm{HNMR}\right.$, relax. delay $1.000 \mathrm{sec}$, pulse 30.0 degrees $)$ and $75.4 \mathrm{MHz}\left({ }^{13} \mathrm{CNMR}\right.$, relax. delay $3.700 \mathrm{sec}$, pulse 45.0 degrees, Waltz-16 modulated). Chemical shifts $(\delta)$ were expressed in parts per million relative to tetramethylsilane used as the internal reference. Mass spectral ESI measurements were carried out on Waters ZQ Micro-mass instruments with quadruple mass analyzer. The spectra were performed in the negative ion mode at a declustering potential of 40-60 V. The sample was previously separated on a UPLC column (C18) using UPLC ACQUITYTM system by Waters connected with DPA detector. Flash chromatography was performed on Merck silica gel 60 (200-400 mesh) using chloroform eluent. Analytical TLC was carried out on silica gel F254 (Merck) plates (0.25 mm thickness).

Synthesis of thiourea derivatives (1-5). A solution of amine derivative (3-(Trifluoromethyl)aniline, 4-chloro-3-nitroaniline, 1,3-thiazol-2-amine, $2 \mathrm{H}$-1,2,3triazol-4-amine) $(0.01 \mathrm{~mol})$ in acetonitrile $(25 \mathrm{ml})$ was treated with appropriate isothiocyanate $(0.011 \mathrm{~mol})$ and the mixture was refluxed for $8 \mathrm{~h}$. Then solvent was removed on rotary evaporator. The residue was purified by column chromatography (chloroform: methanol; 9.5:0.5 vol.). The final product was crystallized from acetonitrile.

1-(1-phenylethyl)-3-[3-(trifluoromethyl)phenyl] thiourea (1). Yield $75 \%$, white powder, m.p. $113-115^{\circ} \mathrm{C}$. ${ }^{1} \mathrm{H}$ NMR (300 MHz, DMSO) $\delta: 9.66(\mathrm{~s}, 1 \mathrm{H}, \mathrm{NH}), 8.42$ $\left(\mathrm{d}, J=7.8 \mathrm{~Hz}, 1 \mathrm{H}, \mathrm{H}_{\text {arom }}\right), 8.03(\mathrm{~s}, 1 \mathrm{H}, \mathrm{NH}), 7.66(\mathrm{~d}$, $\left.J=8.4 \mathrm{~Hz}, 1 \mathrm{H}, \mathrm{H}_{\text {arom }}\right), 7.51\left(\mathrm{t}, 1 \mathrm{H}, J=7.8 \mathrm{~Hz}, \mathrm{H}_{\text {arom }}\right)$, 7.41-7.33 (m, 5H, $\left.\mathrm{H}_{\text {arom }}\right), 7.30-7.23\left(\mathrm{~m}, 1 \mathrm{H}, \mathrm{H}_{\text {arom }}\right)$, 5.55-5.51 (m, 1H, CH), $1.48\left(\mathrm{~d}, J=6.9 \mathrm{~Hz}, 3 \mathrm{H}, \mathrm{CH}_{3}\right)$. ${ }^{13} \mathrm{C}$ NMR (75.4 MHz, DMSO) $\delta: 179.80,143.60$, $140.58,129.50,128.94$ (q), 128.34 (2C), 126.88, 126.24 (2C), 126.05, 124.08 (q), 119.91, 118.59, 52.60, 21.83. HRMS (ESI) calc. for $\mathrm{C}_{16} \mathrm{H}_{14} \mathrm{~F}_{3} \mathrm{~N}_{2} \mathrm{~S}[\mathrm{M}-\mathrm{H}]^{-}: 323.0830$, found: 323.0834 .

1-(3,4-dichlorophenyl)-3-[3-(trifluoromethyl) phenyl]thiourea (2) has been synthesized as described previously (Bielenica et al., 2015).

1,3-bis(4-chloro-3-nitrophenyl)thiourea (3). Yield $40 \%$, yellow powder, m.p. $176-178^{\circ} \mathrm{C} .{ }^{1} \mathrm{H}$ NMR (300 MHz, DMSO) $\delta: 10.47$ (s, 2H, NH), 8.31 (d, 2H, $\left.J=2.4 \mathrm{~Hz}, \mathrm{H}_{\text {arom }}\right), 7.79\left(\mathrm{dd}, 2 \mathrm{H}, J_{1}=J_{2}=2.4 \mathrm{~Hz}, \mathrm{H}_{\text {arom }}\right)$, $7.74\left(\mathrm{~d}, 2 \mathrm{H}, J=8.4 \mathrm{~Hz}, \mathrm{H}_{\text {arom }}\right) \cdot{ }^{13} \mathrm{C}$ NMR $(75.4 \mathrm{MHz}$, DMSO) $\delta: 180.03,147.02$ (2C), 139.16 (2C), 131.50 (2C), 128.73 (2C), 120.16 (2C), 120.09 (2C). HRMS (ESI) calc. for $\mathrm{C}_{13} \mathrm{H}_{8} \mathrm{Cl}_{2} \mathrm{~N}_{4} \mathrm{~S}[\mathrm{M}-\mathrm{H}]^{-}: 385.6756$ found: 385.6759 .

1-(2,3-dichlorophenyl)-3-(1,3-thiazol-2-yl)thiourea (4). Yield $68 \%$, white powder, m.p. $167-169^{\circ} \mathrm{C} .{ }^{1} \mathrm{H}$ NMR (300 MHz, DMSO) $\delta: 12.5$ (s, 1H, NH), 10.21 (s, $1 \mathrm{H}, \mathrm{NH}), 7.75\left(\mathrm{dd}, 1 \mathrm{H}, J_{1}=J_{2}=1.5 \mathrm{~Hz}, \mathrm{H}_{\text {arom }}\right), 7.52(\mathrm{dd}$, $\left.1 \mathrm{H}, J_{1}=J_{2}=1.5 \mathrm{~Hz}, \mathrm{H}_{\text {arom }}\right), 7.44\left(\mathrm{~d}, 1 \mathrm{H}, J=4.2 \mathrm{~Hz}, \mathrm{H}_{\text {arom }}\right)$, 7.37(d, $\left.1 \mathrm{H}, J=3.6 \mathrm{~Hz}, \mathrm{H}_{\text {arom }}\right), 7.06(\mathrm{t}, 1 \mathrm{H}, J=8.1 \mathrm{~Hz}$, $\left.\mathrm{H}_{\text {arom }}\right) .{ }^{13} \mathrm{C}$ NMR $(75.4 \mathrm{MHz}, \mathrm{DMSO}) \delta: 180.03,159.17$, $138.31,137.57,137.15,131.77,128.32,124.46,119.82$, 112.90. HRMS (ESI) calc. for $\mathrm{C}_{10} \mathrm{H}_{7} \mathrm{Cl}_{2} \mathrm{~N}_{3} \mathrm{~S}_{2}[\mathrm{M}-\mathrm{H}]^{-}$: calc. 303.9390 found: 303.9399 .

1-(4-chloro-3-nitrophenyl)-3-(1H-1,2,4-triazol3-yl)thiourea (5). Yield $68 \%$, white powder, m.p. 234-236 ${ }^{\circ} \mathrm{C} .{ }^{1} \mathrm{H}$ NMR (300 MHz, DMSO) $\delta: 14.05$ (s, $1 \mathrm{H}, \mathrm{NH}), 11.96$ (s, 1H, NH), 11.50 (s, 1H, NH), 8.57 $(\mathrm{s}, 1 \mathrm{H}, \mathrm{CH}=) ; 8.11\left(\mathrm{~d}, 1 \mathrm{H}, J=2.4 \mathrm{~Hz}, \mathrm{H}_{\text {arom }}\right), 7.92(\mathrm{dd}$, $\left.1 \mathrm{H}, J_{1}=J_{2}=2.7 \mathrm{~Hz}, \mathrm{H}_{\text {arom }}\right), 7.75\left(\mathrm{~d}, 1 \mathrm{H}, J=8.7 \mathrm{~Hz}, \mathrm{H}_{\text {arom }}\right)$. ${ }^{13} \mathrm{C}$ NMR (75.4 MHz, DMSO) $\delta: 177.58,156.81,148.92$, 
146.91, 142.93, 138.87, 131.41, 129.30, 120.66. HRMS (ESI) calc. for $\mathrm{C}_{9} \mathrm{H}_{7} \mathrm{ClN}_{6} \mathrm{O}_{2} \mathrm{~S}[\mathrm{M}-\mathrm{H}]^{-}$: calc. 296.9969 found: 296.9967.

\section{Biological evaluation}

Antimicrobial studies. Antimicrobial activities of the thiourea derivatives were tested in vitro against six reference Gram-positive strains: S. aureus: NCTC 4163, ATCC 25923, ATCC 6538, ATCC 29213, S. epidermidis: ATCC 12228, ATCC 35984, and against a series 16 of clinical methicillin-resistant S. aureus (MRSA) and S. epidermidis (MRSE) strains. Microorganisms were obtained from the collection of Department of Pharmaceutical Microbiology, Medical University of Warsaw, Poland.

Minimal Inhibitory Concentration (MIC) of tested compounds were examined by the twofold serial broth (Mueller-Hinton Broth medium, Becton Dickinson) dilution methods using 96-well microtitre plates (Medlab Products) according to CLSI guidelines (CLSI, 2012). Concentrations of tested compounds in liquid medium ranged from 0.0625 to $256 \mu \mathrm{g} / \mathrm{ml}$. The final inoculum of all strains studied was about $10^{5} \mathrm{cfu} / \mathrm{ml}$. MIC values were read after $18 \mathrm{~h}$ incubation at $35^{\circ} \mathrm{C}$. Minimal bactericidal concentration of the compounds (MBC - 99.9\% killing of the final inoculums) were determined by subculturing $10 \mu$ of suspension from each negative well (no visible bacterial growth) from the MIC test, onto TSA plates and incubated at $37^{\circ} \mathrm{C}$ for $24 \mathrm{~h}$ (CLSI, 1999). Ciprofloxacin was used as the reference antibacterial drug.

Biofilm inhibitory assay. Three thiourea derivatives $(2,3,5)$ and Ciprofloxacin (as reference antibacterial drug) were studied for their ability to inhibit the formation of staphylococcal biofilm. Selected methicillin-resistant clinical strains of Staphylococcus (four S. aureus and four S. epidermidis) and two reference $S$. epidermidis strains were used in this assay. The clinical strains were isolated from blood of hospitalized patients. S. epidermidis ATCC 35984 was used as high biofilm-producer (positive control), S. epidermidis ATCC 12228 was used as low-biofilm producer (negative control). Ciprofloxacin was the reference antibacterial agent.

Inhibition of bacterial biofilm formation was screened using the method, described previously (Stefańska et al., 2015). All strains were cultured overnight in Tryptic Soy Broth medium supplemented with $0.5 \%$ glucose (BTL, Poland). The solution of tested compounds in above medium was mixed (1:1) with the bacterial inoculums $\left(10^{7} \mathrm{cfu} / \mathrm{ml}\right)$ in sterile 96 -well polystyrene microtiter plates (Karell-Medlab, Italy) and incubated at $37^{\circ} \mathrm{C}$ for $24 \mathrm{~h}$. The final concentrations of tested compounds ranged from 1 to $16 \mu \mathrm{g} / \mathrm{ml}$.
The positive control (biofilm formation) was bacterial culture in TSB-glucose; a negative control was the medium devoid of the bacteria. After incubation, medium was removed from wells and washed twice with sterile PBS buffer (phosphate-buffered saline) to take out the non-adherent bacteria. Adherent bacterial cells, which usually formed biofilm on wells surface, were uniformly stained with 3-(4,5-dimethyl2-thiazolyl)-2,5 diphenyl-2H-tetrazolium bromide (MTT; $0.5 \%$ in PBS) and incubated for 2 hours at $37^{\circ} \mathrm{C}$. After incubation, the solution was removed and bacterial biofilm was solubilized by DMSO (Merck) with glycine buffer ( $\mathrm{pH} 10.2)$ and mixed 15 minutes at room temperature. The solution absorbance $\left(\mathrm{A}_{554}\right)$ was measured at $554 \mathrm{~nm}$ using a spectrophotometer PowerWave XS (BioTek).

The biofilm-inhibition results were interpreted from dose (concentrations) - response graphs.

Due to the transparency image on the graphs shows the results for selected four clinical and two reference strains. Results in the graphs are averages of four repetitions \pm the standard error of the mean. The standard deviation values were very low, is they are sometimes invisible in the figures.

Genotoxicity. DNA-damaging activity of salinomycin and its derivatives was tested by rec-assay using two genetically modified Bacillus subtilis strains: M45 ( $\mathrm{rec}^{-}$) and H17 (rec $)$(Saide and Kada, 1976; Kada et al., 1980). B. subtilis M45 is devoid of the recombinant - based DNA repair mechanism and is much more susceptible to genotoxic substances compared to B. subtilis $\mathrm{H} 17$ strain. Tested compounds were dissolved in DMSO and $10 \mu \mathrm{l}$ of each solution were dripped onto sterile filter paper discs (Whatman No 3MM) to load $256 \mu$ of a given compound per $9 \mathrm{~mm}$ disc. Discs were placed on the surface of Nutrient agar plates (BTL, Poland) inoculated with $100 \mu \mathrm{l}$ of bacterial culture overnight and incubated for $24 \mathrm{~h}$ at $35^{\circ} \mathrm{C}$. After incubation the growth inhibition zones were measured. NOQ (4-nitroquinoline $\mathrm{N}$-oxide) was used as the reference genotoxin in concentration $2 \mu \mathrm{g}$ per disc.

Results of the genotoxicity test were read after $18 \mathrm{~h}$ of incubation at $35^{\circ} \mathrm{C}$ by comparing the diameter of the inhibition zone for the B. subtilis M45 ( $\left.\mathrm{rec}^{-}\right)$strain with that observed for the B. subtilis $\mathrm{H} 17\left(\mathrm{rec}^{+}\right)$strain.

\section{Inhibition of bacterial topoisomerase IV}

Decatenation assay. The assay was performed using S. aureus topoisomerase IV decantation kit (Inspiralis). Kinetoplast DNA (kDNA) was the substrate for topoisomerase IV. $1 \mathrm{U}$ of topoisomerase IV decatenated $200 \mathrm{ng}$ of $\mathrm{kDNA}$, in the dedicated decantation assay buffer supplied by the manufacturer. Enzyme activity was detected by incubation for $30 \mathrm{~min}$ at $37^{\circ} \mathrm{C}$ in 
a total reaction volume of $30 \mu \mathrm{l}$ and in the presence of different concentrations of the test compounds. The reactions were terminated by adding an equal volume of STEB buffer ( $40 \%$ sucrose, $100 \mathrm{mM}$ Tris- $\mathrm{HCl} \mathrm{pH} 8$, $1 \mathrm{mM}$ EDTA, $0.5 \mathrm{mg} / \mathrm{ml}$ bromophenol blue), followed by extraction with 1 volume of chloroform/isoamyl alcohol (24:1).

Then, $20 \mu \mathrm{l}$ of the aqueous phase of each sample was loaded onto a $1 \%$ agarose gel. Electrophoresis was conducted in Tris-acetate-EDTA buffer for $1.5 \mathrm{~h}$ at $80 \mathrm{~V}$. Gels were stained with ethidium bromide and visualized under UV light in a transilluminator (ChemiDoc MP, Bio Rad).

\section{Results}

The preparation of 5 thiourea derivatives was accomplished according the reactions described in Scheme 1.

The first step was to determine the antibacterial activity of tested thiourea derivatives against standard and clinical methicillin-resistant S. aureus (MRSA) and S. epidermidis strains (MRSE). Moreover derivatives were tested for their genotoxicity, ability to inhibition biofilm formation by various clinical Staphylococcus strains and activity of selected compounds against bacterial topoisomerase.

Antibacterial activities of tested compounds were expressed by minimal inhibitory concentration (MIC) and minimal bactericidal concentration (MBC). The results were listed in Tables I-II. Two derivatives, 2 and 3 showed very potent anti-staphylococcal activity. For the compound $2 \mathrm{MIC}$ values were from 0.5 to $1.0 \mu \mathrm{g} / \mathrm{ml}$ and $\mathrm{MBC}$ values ranged from 4 to $8 \mu \mathrm{g} / \mathrm{ml}$.
For compound 3 MIC values ranged from $2 \mu \mathrm{g} / \mathrm{ml}$ to $8 \mu \mathrm{g} / \mathrm{ml}$ and $\mathrm{MBC}$ values was $256 \mu \mathrm{g} / \mathrm{ml}$ and above. For the reference antibacterial agent - Ciprofloxacin MIC values ranged from $0.125 \mu \mathrm{g} / \mathrm{ml}$ to $0.5 \mu \mathrm{g} / \mathrm{ml}$ and MBC values ranged from $0.5 \mu \mathrm{g} / \mathrm{ml}$ to $2 \mu \mathrm{g} / \mathrm{ml}$ for standard Staphylococcus strains. For clinical methicillinresistant isolates Ciprofloxacin MIC values ranged from $0.5 \mu \mathrm{g} / \mathrm{ml}$ to $64 \mu \mathrm{g} / \mathrm{ml}$ and $\mathrm{MBC}$ values ranged from $4 \mu \mathrm{g} / \mathrm{ml}$ to above $256 \mu \mathrm{g} / \mathrm{ml}$.

Only for the compound 2 the bactericidal activity was observed at a low concentration $(4-8 \mu \mathrm{g} / \mathrm{ml})$. Compounds 1 and 3 showed only bacteriostatic effect (MBC values much higher as compared to the MIC values). Compound 4 and 5 showed weak activity against tested staphylococcal strains.

Sometimes antimicrobial activity of various compounds is directly connected with their genotoxicity. This effect is not profitable to microbiologically active compounds. Genotoxicity of thiourea derivatives was tested by rec-assay using two genetically modified Bacillus subtilis strains: $\mathrm{H} 17\left(\mathrm{rec}^{+}\right)$and M45 ( $\left.\mathrm{rec}^{-}\right)$. B. subtilis M45 is more susceptible to genotoxic substances (for example NOQ) compared to B. subtilis H17 strain. As shown in Table III there was no significant difference in the diameter of the inhibition zones for both bacterial strains. Examined compounds are nongenotoxic in vitro for the tested bacterial cells.

Three of obtained compounds were tested for their ability to inhibit the staphylococcal biofilm formation. Four selected clinical isolates (four S. aureus and four S. epidermidis isolated from blood of hospitalized patients) and two standard S. epidermidis strains (positive and negative control) were used in this study. The biofilm inhibitory activity of derivatives 2 and 3

Table I

In vitro activity of tested compounds against planktonic cells of standard and clinical methicillin-resistant $S$. aureus strains.

\begin{tabular}{|l|c|c|c|c|c|c|}
\hline No. S. aureus & $\begin{array}{c}\mathbf{1} \\
\text { MIC (MBC) }\end{array}$ & $\begin{array}{c}\mathbf{2} \\
\text { MIC (MBC) }\end{array}$ & $\begin{array}{c}\mathbf{3} \\
\text { MIC (MBC) }\end{array}$ & $\begin{array}{c}\mathbf{4} \\
\text { MIC (MBC) }\end{array}$ & $\begin{array}{c}\mathbf{5} \\
\text { MIC (MBC) }\end{array}$ & $\begin{array}{c}\text { Ref }^{*} \\
\text { MIC (MBC) }\end{array}$ \\
\hline NCTC 4163 & $16(>256)$ & $0.5(4)$ & $4(256)$ & $64(>256)$ & $64(>256)$ & $0.25(0.5)$ \\
\hline ATCC 25923 & $16(>256)$ & $0.5(4)$ & $8(>256)$ & $64(>256)$ & $64(>256)$ & $0.5(2)$ \\
\hline ATCC 6538 & $16(>256)$ & $0.5(4)$ & $8(>256)$ & $32(>256)$ & $64(>256)$ & $0.25(1)$ \\
\hline ATCC 29212 & $16(>256)$ & $0.5(4)$ & $4(256)$ & $64(>256)$ & $128(>256)$ & $0.5(2)$ \\
\hline $\mathbf{4 5 2 / 1 1}$ & $32(>256)$ & $0.5(4)$ & $2(256)$ & $64(>256)$ & $128(>256)$ & $32(>256)$ \\
\hline $\mathbf{4 6 2 / 1 1}$ & $16(>256)$ & $1(8)$ & $2(256)$ & $64(>256)$ & $256(>256)$ & $64(>256)$ \\
\hline $\mathbf{5 1 4 / 1 2}$ & $16(>256)$ & $1(8)$ & $8(>256)$ & $64(>256)$ & $64(>256)$ & $32(256)$ \\
\hline $\mathbf{5 2 2 / 1 2}$ & $16(>256)$ & $1(8)$ & $4(>256)$ & $32(>256)$ & $64(>256)$ & $64(>256)$ \\
\hline $\mathbf{5 7 2 / 1 2}$ & $32(>256)$ & $0.5(4)$ & $8(>256)$ & $32(>256)$ & $256(>256)$ & $64(>256)$ \\
\hline $\mathbf{5 7 3 / 1 2}$ & $16(>256)$ & $1(8)$ & $2(256)$ & $64(>256)$ & $128(>256)$ & $32(256)$ \\
\hline $\mathbf{5 8 5 / 1 2}$ & $16(>256)$ & $0.5(4)$ & $4(>256)$ & $32(>256)$ & $128(>256)$ & $64(>256)$ \\
\hline $\mathbf{5 8 6 / 1 2}$ & $16(>256)$ & $0.5(4)$ & $2(256)$ & $64(>256)$ & $256(>256)$ & $64(>256)$ \\
\hline
\end{tabular}

Ref $^{\star}$ - Ciprofloxacin (reference antimicrobial drug), MIC - minimal inhibitory concentration $(\mu \mathrm{g} / \mathrm{ml})$, $\mathrm{MBC}$ - minimal bactericidal concentration $(\mu \mathrm{g} / \mathrm{ml})$. 
Table II

In vitro activity of tested compounds against planktonic cells of standard and clinical methicillin-resistant S. epidermidis strains.

\begin{tabular}{|l|c|c|c|c|c|c|}
\hline $\begin{array}{c}\text { No. } \\
\text { S. epidermidis }\end{array}$ & $\begin{array}{c}\mathbf{1} \\
\text { MIC }(\mathrm{MBC})\end{array}$ & $\begin{array}{c}\mathbf{1} \\
\text { MIC }(\mathrm{MBC})\end{array}$ & $\begin{array}{c}\mathbf{1} \\
\mathrm{MIC}(\mathrm{MBC})\end{array}$ & $\begin{array}{c}\mathbf{1} \\
\mathrm{MIC}(\mathrm{MBC})\end{array}$ & $\begin{array}{c}\mathbf{1} \\
\text { MIC }(\mathrm{MBC})\end{array}$ & $\begin{array}{c}\text { Ref.* }^{*} \\
\text { MIC }(\mathrm{MBC})\end{array}$ \\
\hline ATCC $\mathbf{1 2 2 2 8}$ & $32(>256)$ & $1(8)$ & $4(256)$ & $64(>256)$ & $128(>256)$ & $0.25(1)$ \\
\hline ATCC 35984 & $32(>256)$ & $1(8)$ & $4(256)$ & $32(256)$ & $64(>256)$ & $0.125(0.5)$ \\
\hline $\mathbf{4 0 9 / 1 1}$ & $16(>256)$ & $1(8)$ & $2(>256)$ & $32(>256)$ & $128(>256)$ & $2(32)$ \\
\hline $\mathbf{4 5 5 / 1 1}$ & $16(>256)$ & $0.5(4)$ & $2(>256)$ & $64(>256)$ & $128(>256)$ & $32(256)$ \\
\hline $\mathbf{4 5 9 / 1 1}$ & $16(>256)$ & $0.5(4)$ & $4(>256)$ & $32(>256)$ & $64(>256)$ & $32(256)$ \\
\hline $\mathbf{4 6 9 / 1 1}$ & $16(>256)$ & $0.5(4)$ & $4(>256)$ & $64(>256)$ & $128(>256)$ & $8(64)$ \\
\hline $\mathbf{5 1 7 / 1 2}$ & $16(>256)$ & $1(8)$ & $2(>256)$ & $32(>256)$ & $128(>256)$ & $32(256)$ \\
\hline $\mathbf{5 1 9 / 1 2}$ & $16(>256)$ & $1(8)$ & $2(>256)$ & $32(>256)$ & $64(>256)$ & $0.5(4)$ \\
\hline $\mathbf{5 2 6 / 1 2}$ & $32(>256)$ & $0.5(4)$ & $4(>256)$ & $64(>256)$ & $128(>256)$ & $4(32)$ \\
\hline $\mathbf{5 2 8 / 1 2}$ & $16(>256)$ & $1(8)$ & $4(>256)$ & $64(>256)$ & $128(>256)$ & $32(256)$ \\
\hline
\end{tabular}

$\operatorname{Ref}^{*}$ - Ciprofloxacin (reference antimicrobial drug), MIC - minimal inhibitory concentration $(\mu \mathrm{g} / \mathrm{ml})$,

$\mathrm{MBC}$ - minimal bactericidal concentration $(\mu \mathrm{g} / \mathrm{ml})$.

Table III

Genotoxicity of tested compounds in rec-assay.

Concentration of tested compounds $-256 \mu \mathrm{g}$ per $9 \mathrm{~mm}$ disc. ${ }^{*} \mathrm{NOQ}$ (4-nitroquinoline $\mathrm{N}$-oxide) - reference genotoxic agent, $2 \mu \mathrm{g}$ per $9 \mathrm{~mm}$ disc

\begin{tabular}{|c|c|c|}
\hline \multirow{2}{*}{ Tested compound } & \multicolumn{2}{|c|}{ Diameter of growth inhibition zones $(\mathrm{mm})$} \\
\cline { 2 - 3 } & $\begin{array}{c}\text { Bacillus subtilis } \\
\text { H17 }\left(\mathrm{rec}^{+}\right)\end{array}$ & $\begin{array}{c}\text { Bacillus subtilis } \\
\text { M45 (rec }\end{array}$ \\
\hline 1 & 12 & 12 \\
\hline 2 & na & na \\
\hline 3 & 14 & 13 \\
\hline 4 & na & na \\
\hline 5 & na & na \\
\hline NOQ $^{*}$ & 12 & 24 \\
\hline
\end{tabular}

na - no growth inhibition zone

were higher than the reference agent - Ciprofloxacin (Fig. 1-4). The more active compound 2 inhibited biofilm formation in the range from $40 \%$ to above $90 \%$ in concentration $1 \mu \mathrm{g} / \mathrm{ml}$ (MIC for planktonic cells) (Fig. 1). The same concentration of compound 3 caused inhibition of bacterial biofilm formation in 30\% to $50 \%$ by 5 of 10 tested strains (Fig. 2).

Biofilm inhibitory activity of tested thiourea derivatives 2 and 3 is the result of inhibiting of multiplication of bacterial cells, in consequence they prevent from biofilm formation and reduce its amount. In the presence of the compound 2 the lower amount of staphylococcal biofilm was produced and it was more susceptible to the mechanical damage and removal of the staining process, as shown in the Figure 5.

The last step was the investigation of mechanism of the antimicrobial activity. Considering the results in the in vitro antibacterial assay, we have investigated the inhibitory effect on topoisomerase IV of compounds 2 and 3, showed highest therapeutic potential against strains of S. aureus and S. epidermidis, including clinically relevant resistant isolates. Compounds 2 and 3 were used in wide range of concentrations $(32 \mu \mathrm{g} / \mathrm{ml}$, $8 \mu \mathrm{g} / \mathrm{ml}, 2 \mu \mathrm{g} / \mathrm{ml}, 0.5 \mu \mathrm{g} / \mathrm{ml}, 0.25 \mu \mathrm{g} / \mathrm{ml}$ ).

The affinity of the selected compounds towards bacterial type II topoisomerases, such as topoisomerase IV from S. aureus was analysed. The results obtained

$$
\mathrm{R} \frac{1}{-} \mathrm{NH}_{2}+\mathrm{R}-\left.\mathrm{NCS} \stackrel{\text { (i) }}{\longrightarrow}\right|_{(1-5)} ^{\mathrm{NH}-\mathrm{R}^{1}}
$$

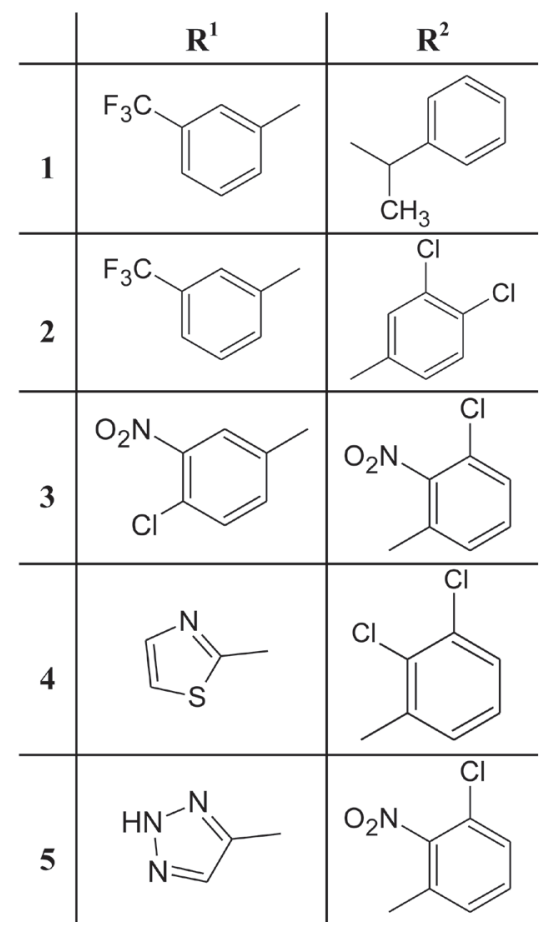

Scheme 1. Synthesis and structure of tested compounds. Reagents and conditions: (i) $\mathrm{MeCN}$, reflux $8 \mathrm{~h}$. 


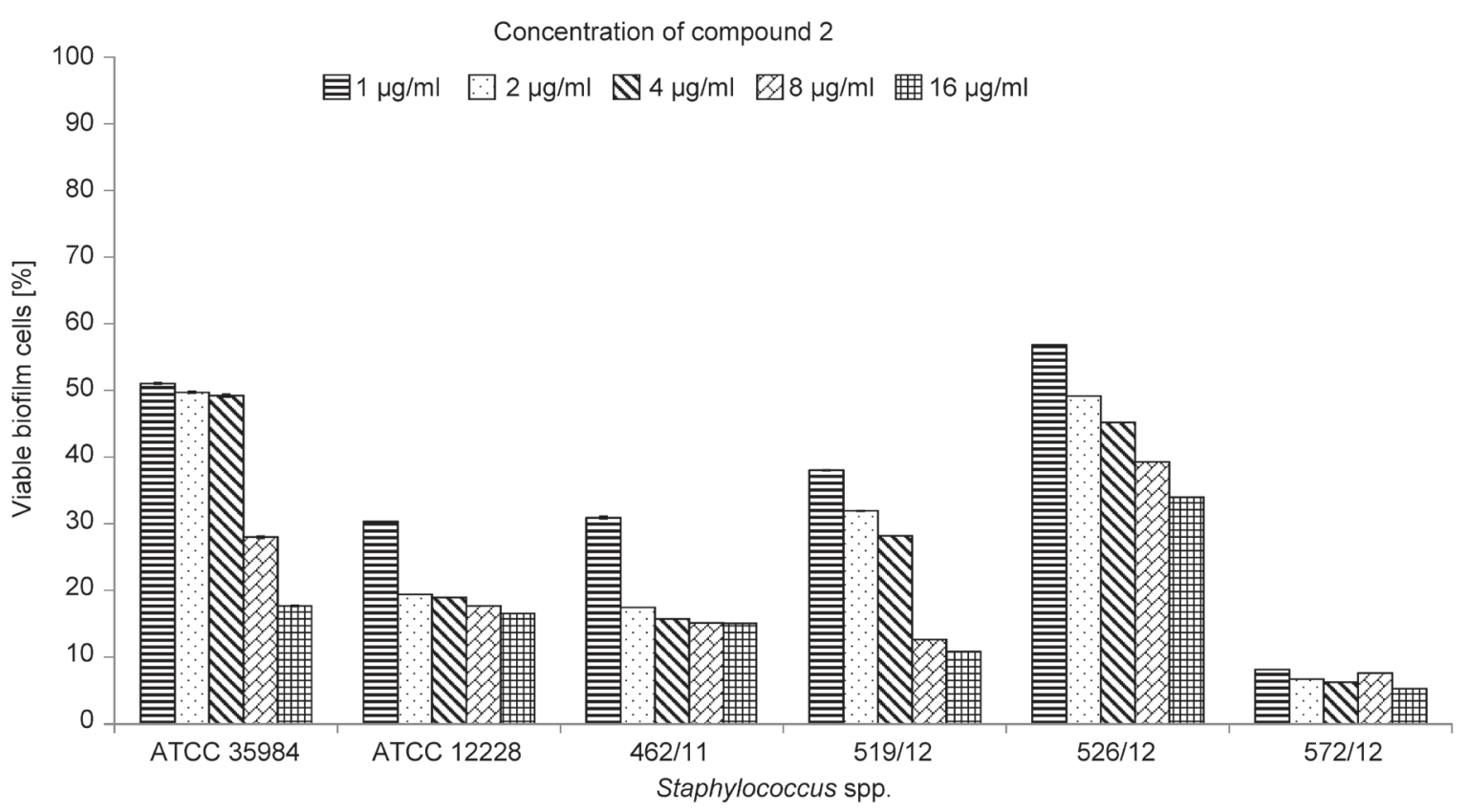

Fig. 1. Inhibitory effect of compound 2 for biofilm formation by standard and selected hospital methicillin-resistant Staphylococcus spp. strains.

All presented results are mean from experiments performed in quadruplicate \pm S.D.

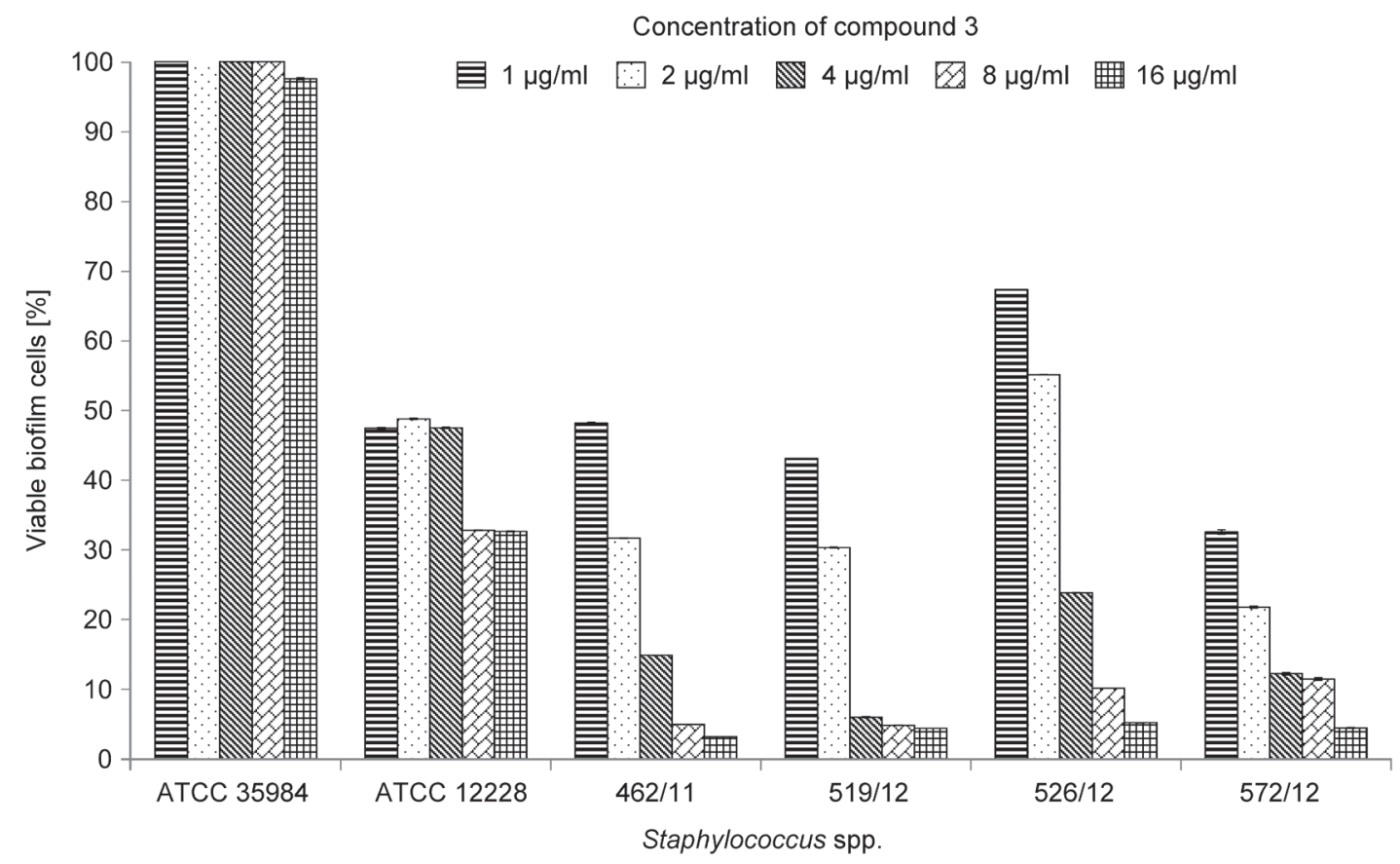

Fig. 2. Inhibitory effect of compound 3 for biofilm formation by standard and selected hospital methicillin-resistant Staphylococcus spp. strains.

All presented results are mean from experiments performed in quadruplicate \pm S.D.

demonstrated that synthesized compound 2 applied at concentration $32 \mu \mathrm{g} / \mathrm{ml}$ was equally active as Ciprofloxacin, however the compound 3 did not show inhibitory potency towards S. aureus topoisomerase IV (Fig. 6). For 3 the inhibition of bacterial type II topoisomerases in not the sole factor responsible for the antibacterial activity.

\section{Discussion}

When the effect of the substituent at thiourea nitrogen (N1) was evaluated, it was found that the functionalities could be valued in order of their decreasing influence as follows: 3-trifluoromethylphenyl $>4$-chloro-3-nitrophenyl >1,3-thiazol $>2 \mathrm{H}$-1,2,3-tria- 


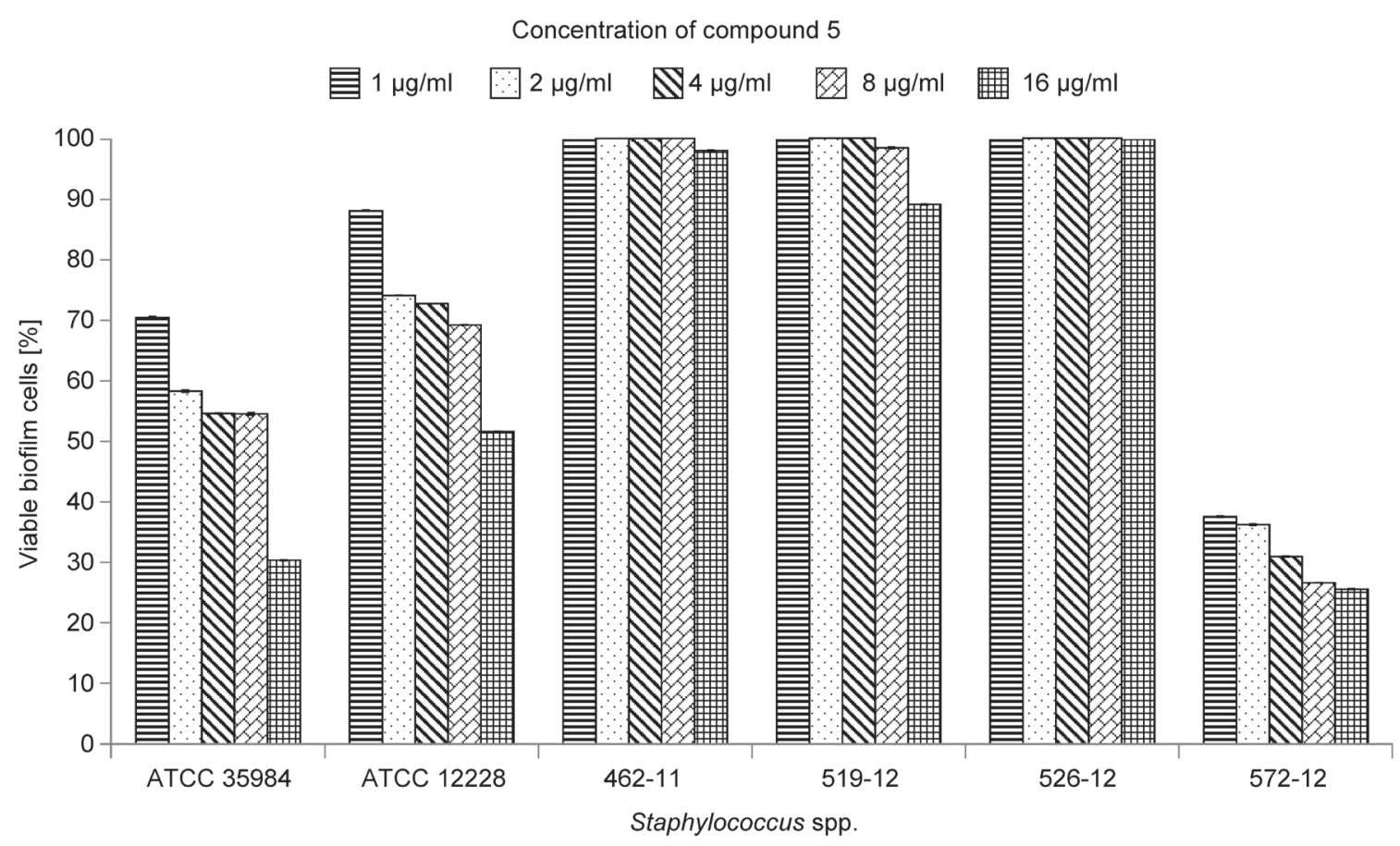

Fig. 3. Inhibitory effect of compound 5 for biofilm formation by standard and selected hospital methicillin-resistant Staphylococcus spp. strains.

All presented results are mean from experiments performed in quadruplicate \pm S.D.

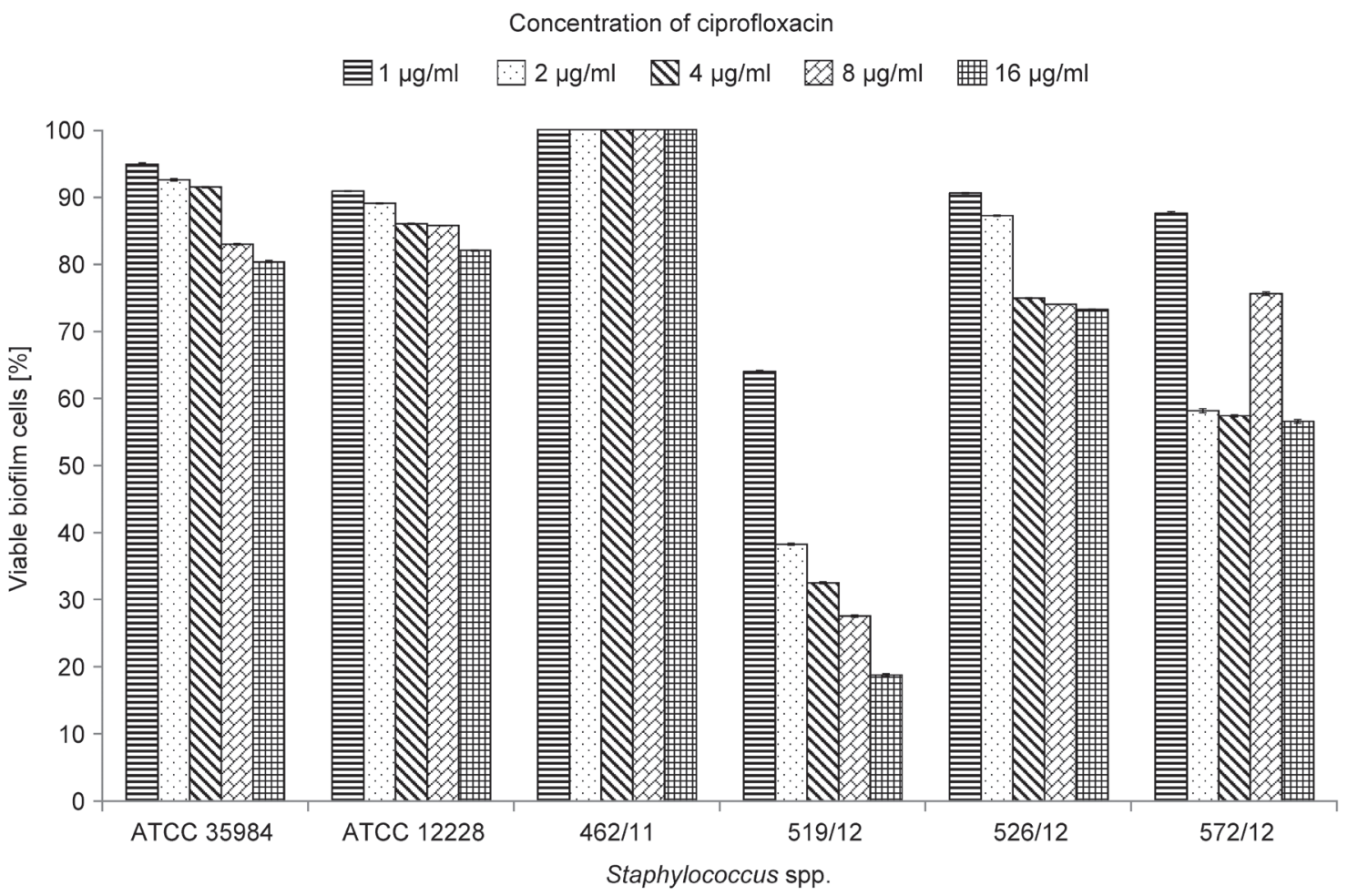

Fig. 4. Inhibitory effect of ciprofloxacin for biofilm formation by standard and selected hospital methicillin-resistant Staphylococcus spp. strains.

All presented results are mean from experiments performed in quadruplicate \pm S.D.

zol. Interesting was activity comparison of activity of compound 1 and 2 because only substituent connected to N2 nitrogen atom was changed. Antimicrobial activity decreased when between thiourea and aryl substit- uent alkyl group was introduced. Only compound 2 with trifluoromethylphenyl and 3,4-dichlorophenyl connected to thiourea moiety possessed bactericidal activity (Tables I, II). The rest of tested compounds 

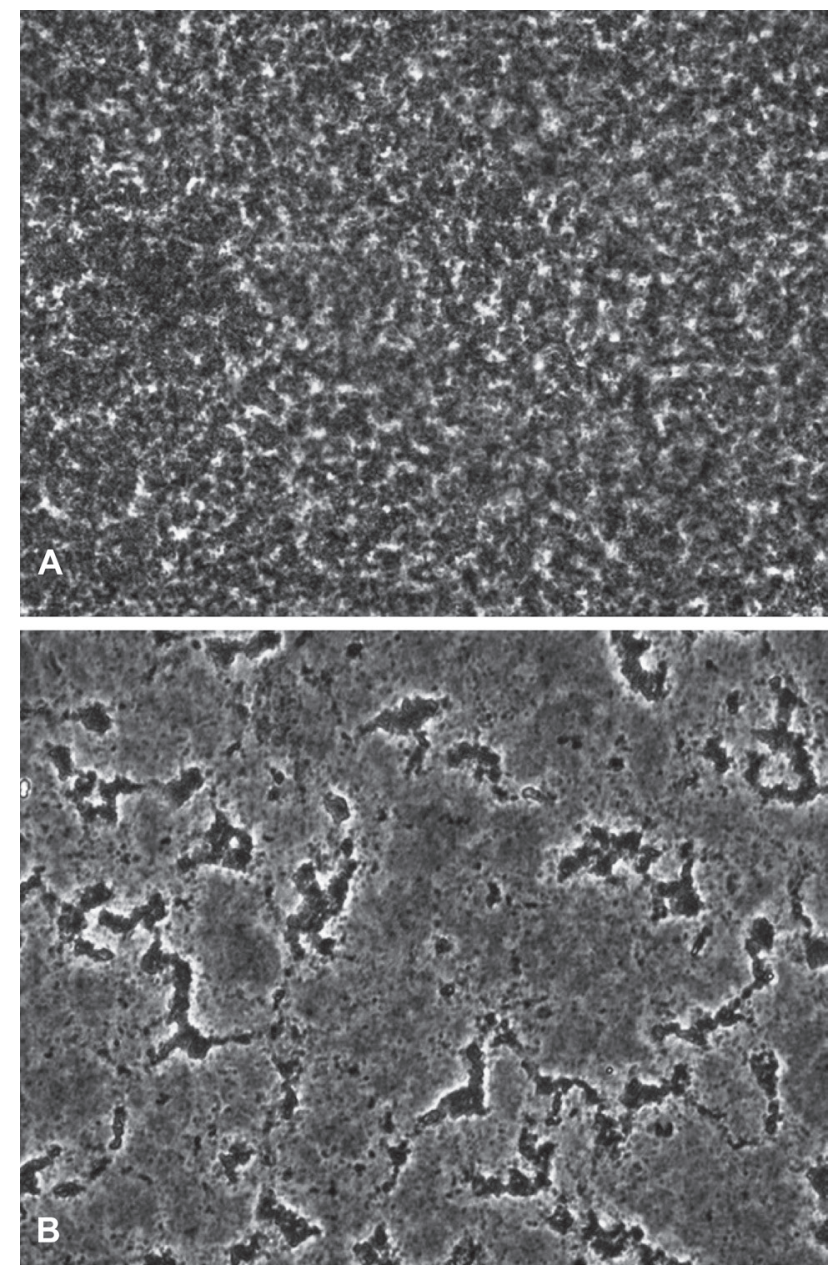

Fig. 5. Biofilms of S. epidermidis ATCC 35984 growth for $24 \mathrm{~h}$ on polystyrene microtiter plates: A - in TSB medium supplemented with $0.5 \%$ glucose; B - in TSB medium supplemented with $0.5 \%$ glucose in the presence of compound 2 in concentration $1 \mu \mathrm{g} / \mathrm{ml}$. The digital images were visualized using the phase-contrast inverted microscope Eclipse TS 100F Inverted Routine Microscopes (Nikon, USA) equipped with the DeltaPix Invenio 5SCII camera using DeltaPixInSigh software.

showed bacteriostatic effect (MBC values much higher compared to the MIC values).

3-(Trifluoromethyl)aniline, 4-chloro-3-nitroaniline, 1,3-thiazol-2-amine, $2 \mathrm{H}$-1,2,3-triazol-4-amine were subjected to the reaction with isothiocyanates to obtain thiourea derivatives (Scheme 1). To assure structural variability, different aryl, heteroaryl and aryl con- nected by methylene group at thiourea moiety were introduced. Whereas unsubstituted 1,3-diphenylthiourea exerts no relevant antimicrobial activity (Cunha et al., 2007), howewer its various structural modifications improve the biological effectiveness of a compound (Mishra and Batra, 2013). Literature survey reveals that incorporation of halogen atom(s) within the molecule is one of the most effective strategies to enhance its biopotency, bioavailability and lipophilicity. The fluoro-containing arylthiourea compounds show better activity as compared to other analogues (Suresha et al., 2011), however fluoro-methyl substituent on the benzene ring also improve antimicrobial potency (Bielenica et al., 2015). According to other authors findings (Chikhalia and Patel, 2009; Saeed et al., 2009; 2010; Faidallah et al., 2013), the antibacterial and antifungal efficacy depends on the presence of such electron withdrawing $\left(\mathrm{NO}_{2}, \mathrm{Cl}, \mathrm{CF}_{3}\right)$ substituent at $\mathrm{C}-2$ and $\mathrm{C}-4$ position of the phenyl ring.

In this work in order to assure structural variability, different aryl substituents connected to N1 and N2 atom of thiourea moiety were introduced and the biological activity depended on the structure of new thiourea derivatives.

Potent Gram-positive antibacterial activity of several analogs of thiourea, urea (Ehmann and Lahiri, 2014) and thiosemicarbazide derivatives (Siwek et al., 2011 ) is explained by an inhibition of the catalytic site of bacterial type II topoisomerases, in particular DNA gyrase and topoisomerase IV. Topoisomerase IV is a bacterial type II topoisomerase that is essential for proper chromosome segregation and is a target for quinolone-based antimicrobial agents, such as Ciprofloxacin and Levofloxacin (Fournier et al., 2000).

Fluoroquinolones stimulate topoisomerase IV-mediated DNA cleavage both by increasing rate of DNA scission and by inhibiting relegation of cleaved DNA. As a result, quinolones inhibit the overall catalytic activity of topoisomerase IV by interfering with enzyme-ATP interactions (Anderson et al., 1998). Presented preliminary results showed that thiourea-derived compounds presented in this study were able to inhibit the activity of bacterial topoisomerases, such as S. aureus topoisomerase IV.

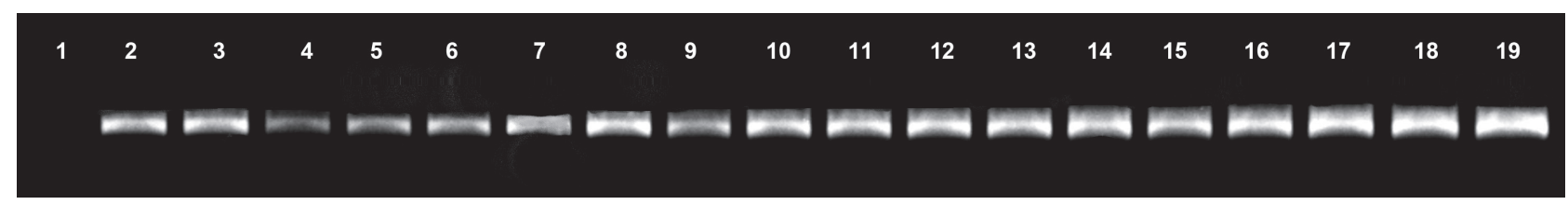

Fig. 6. The effect of studied compounds on topoisomerase IV in decatenation assays: 1 - control assay without enzyme; 2 - S. aureus topoisomerase IV control; 3 - S. aureus topoisomerase IV control with DMSO; 4 - Ciprofloxacin (CFX) $(96 \mu \mathrm{g} / \mathrm{ml}), 5$ - CFX (32 $\mu \mathrm{g} / \mathrm{ml})$, 6 - CFX $(8 \mu \mathrm{g} / \mathrm{ml}), 7$ - CFX $(4 \mu \mathrm{g} / \mathrm{ml}), 8$ - CFX $(2 \mu \mathrm{g} / \mathrm{ml}) ; 9$ - compound $2(32 \mu \mathrm{g} / \mathrm{ml}), 10$ - comp. $2(8 \mu \mathrm{g} / \mathrm{ml}), 11-\mathrm{comp} .2(4 \mu \mathrm{g} / \mathrm{ml})$, 12 - comp. $2(1 \mu \mathrm{g} / \mathrm{ml}), 13$ - comp. $2(0.5 \mu \mathrm{g} / \mathrm{ml}), 14$ - comp. $2(0.25 \mu \mathrm{g} / \mathrm{ml}) ; 15$ - comp. $3(32 \mu \mathrm{g} / \mathrm{ml}) ; 16$ - comp. $3(8 \mu \mathrm{g} / \mathrm{ml})$, 17 - comp. $3(4 \mu \mathrm{g} / \mathrm{ml}), 18$ - comp. $3(1 \mu \mathrm{g} / \mathrm{ml}), 18$ - comp. $3(0.5 \mu \mathrm{g} / \mathrm{ml})$. 
It is known, that 3-(trifluoromethyl)phenyl]thiourea derivatives, close analogs of 1 and 2, are not cytotoxic against normal (HaCaT) cells (Bielenica et al., 2015). They do not considerably decreased viability and have no visible influence on the mortality of tested cells. Similar tests for thiourea compounds presented in that paper will be conducted in the near future. To exploit their antibiofilm properties, the title compounds could be used to cover the surface of biomaterials or medical devices.

\section{Acknowledgments}

Research subject carried out with the use of CePT infrastructure financed by the European Union - the European Regional Development Fund within the Operational Programme "Innovative economy for 2007-2013".

\section{Conflicts of interest}

All authors declare, that there are not any potential conflicts of interest.

\section{Literature}

Agarwal A., K.P. Singh and A. Jain. 2010. Medical significance and management of staphylococcal biofilm. FEMS Immunol. Med. Microbiol. 58: 147-160.

Anderson V.E, T.D. Gootz and N. Osheroff. 1998. Topoisomerase IV catalysis and the mechanism of quinolone action. J. Biol. Chem. 273: 17879-17885.

Arciola C.R., D. Campoccia, S. Gamberini, M.E. Donati, V. Pirini, L. Visai, P. Speziale and L. Montanaro. 2005. Antibiotic resistance in expolysaccharide-forming Staphylococcus epidermidis clinical isolated from orthopedic implant infections. Biomaterial 26 6530-6535.

Basarab G.S., J. Manchester, S. Bist, P.A. Boriack-Sjodin, B. Dangel, R. Illingworth, B.A. Sherer, S. Sriram, M. Uria-Nickelsen and A.E. Eakin. 2013. Fragment-to-hit-to-lead discovery of a novel pyridylurea scaffold of ATP competitive dual targeting type II topoisomerase inhibiting antibacterial agents. J. Med. Chem. 56: 8712-8735. Bielenica A., J. Stefańska, K. Stępień, A. Napiórkowska, E. Augustynowicz-Kopeć, G. Sanna, S. Madeddu, S. Boi, G. Giliberti, M. Wrzosek and othres. 2015. Synthesis, cytotoxicity, antimicrobial activity of thiourea derivatives incorporatinf 3-(trifluoromethyl) phenyl moiety. Eur. J. Med. Chem. 101: 111-125.

Bridier A., R. Brandet, V. Thomas and F. Dubois-Brissonnet. 2011. Resistance of bacterial biofilms to desinfectants: a review. Biofouling 27: 1017-1032.

Chambers H.F. and F.R. DeLeo. 2009. Waves of resistance: Staphylococcus aureus in the antibiotic area. Nat. Rev. Microbiol. 7: 629-641 Chikhalia K.H. and M.J. Patel. 2009. Design, synthesis and evaluation of some 1,3,5-triazinyl urea and thiourea derivatives as antimicrobial agents. J. Enz. Inhib. Med. Chem. 24: 960-966.

Clinical and Laboratory Standards Institute (CLSI). 1999. Methods for determining bactericidal activity of antimicrobial agents - approved guideline M26-A. Wayne, Pennsylvania, USA.

Clinical and Laboratory Standards Institute (CLSI). 2012. Methods for dilution antimicrobial susceptibility tests for bacteria that grow aerobically - approved Standard M7-A9. Pennsylvania, USA.

Costerton J.W., P.S. Stewart and E.P. Greenberg. 1999. Bacterial biofilms: a common cause of persistent infections. Science 284: 1318-1322.
Cunha S., F.C. Macedo Jr., G.A.N Costa, M.T. Rodrigues Jr., R.B.V. Verde, L.C de Souza Neta, I. Vencato, C. Lariucci and F.P. Sá. 2007. Antimicrobial activity and structural study of disubstituted thiourea derivatives. Monatsh. Chem. 138: 511-516.

Donlan R.M. 2001. Biofilms and device - associated infections. Emerg. Infect. Disc. 7: 277-281.

Donlan R.M. and J.W. Costerton. 2002. Biofilms: survival mechanisms of clinically relevant microorganisms. Clin. Microbiol. Rev. 15: $167-193$.

Ehmann D.M. and S.D. Lahiri. 2014. Novel compounds targeting bacterial DNA topoisomerase/DNA gyrase. Curr. Opin. Pharmacol. 18: 76-83.

Faidallah H.M., S.A. Rostom, S.A. Basaif, M.S. Makki and K.A. Khan. 2013. Synthesis and biological evaluation of some novel urea and thiourea derivatives of isoxazolo[4,5-d]pyridazine and structurally related thiazolo[4,5-d]pyridazine as antimicrobial agents. Arch. Pharm. Res. 36: 1354-1368.

Fournier B., X. Zhao, T. Lu, K. Drlica and D.C. Hooper. 2000. Selective Targeting of Topoisomerase IV and DNA gyrase in Staphylococcus aureus: different patterns of quinolone-induced inhibition of DNA synthesis. Antimicrob. Agents Chemother. 44: 2160-2165. Heczko P.B., M. Wróblewska and A. Pietrzyk (eds). 2014. Microbiology (in Polish). Wydawnictwo Lekarskie PZWL, Warszawa. Høiby N., T. Bjarnsholt, M. Givscov, S. Molin and O. Ciofu. 2010. Antibiotic resistance of bacterial biofilms. Int. J. Antimicrob. Agents 35: 322-332.

Kada T., K. Hirano and Y. Shirasu. 1980. Bacillus subtilis recassay test. In: Seeres F.J. and A. Hollaender (eds). Chemical Mutagens 6: 149-173.

Keche A.P., G.D. Hatnapure, R.H. Tale, A.H. Rodge and V.M. Kamble. 2012. Synthesis, anti-inflammatory and antimicrobial evaluation of novel 1-acetyl-3,5-diaryl-4,5-dihydro $(1 \mathrm{H})$ pyrazole derivatives bearing urea, thiourea and sulfonamide moieties. Bioorg. Med. Chem. Lett. 22: 6611-6615.

Leclercq R. 2009. Epidemiological and resistance issues in multidrug-resistant staphylococci and enterococci. Clin. Microbiol. Infect. 15: 224-231.

Mack D., H. Rohde, L.G. Harris, A.P. Davies, M.A. Horstkotte and J.K. Knobloch. 2006. Biofilm formation in medical device-related infection. Int. J. Artif. Organs 29: 343-359.

Maki D.G., D.M. Kluger and C.J. Crinch. 2006. The risk of bloodstream infection in adults with different intravascular devices. A systematic review of 200 published prospective studies. Mayo Clin. Proc. 81: 1159-1171.

Meng C., Y. Qingsong and S. Hongmin. 2013. Novel strategies for the prevention and treatment of biofilm related infections. Int. J. Mol. Sci. 14: 18488-18501.

Mishra A. and S. Batra. 2013. Thiourea and guanidine derivatives as antimalarial and antimicrobial agents. Curr. Top. Med. Chem. 13: 2011-2025.

Otto M. 2008. Staphylococcal biofilms. Curr. Top Microbiol. Immunol. 322: 207-228.

Otto M. 2009. Staphylococcus epidermidis - The "accidental" pathogen. Nat. Rev. Microbiol. 7: 555-557.

Ranise A., A. Spallarossa, S. Schenone, O. Bruno, F. Bondavalli, L. Vargiu, T. Marceddu, M. Mura, P. La Colla and A. Pani. 2003. Design, synthesis, SAR, and molecular modeling studies of acylthiocarbamates: a novel series of potent non-nucleoside HIV-1 reverse transcriptase inhibitors structurally related to phenethylthiazolylthiourea derivatives. J. Med. Chem. 46: 768-781.

Sadaie Y. and T. Kada. 1976. Recombination-deficient mutants of Bacillus subtilis. J. Bacteriol. 125: 489-500.

Saeed A., U. Shaheen, A. Hameed and S.H.Z. Naqvi. 2009. Synthesis, characterization and antimicrobial activity of some new 1-(fluorobenzoyl)-3-(fluorophenyl)thioureas. J. Fluor. Chem. 130: 1028-1034. 
Saeed S., N. Rashid, P.G. Jones, M. Ali and R. Hussain. 2010. Synthesis, characterization and biological evaluation of some thiourea derivatives bearing benzothiazole moiety as potential antimicrobial and anticancer agents. Eur. J. Med. Chem. 45: 1323-1331.

Siwek A., P. Stączek and J. Stefańska. 2011. Synthesis and structureactivity relationship studies of 4-arylthiosemicarbazides as topoisomerase IV inhibitors with Gram-positive antibacterial activity. Search for molecular basis of antibacterial activity of thiosemicarbazides. Eur. J. Med. Chem. 46: 5717-5726.

Stefańska J., G. Nowicka, Struga M, D. Szulczyk, A.E. Kozioł E. Augustynowicz-Kopeć, A. Napiórkowska, A. Bielenica, W. Filipowski and others. 2015. Antimicrobial and anti-biofilm activity of thiourea derivatives incorporating a 2-aminothiazole scaffold. Chem. Pharm. Bull. 63: 1-12.
Struga M., S. Rosołowski, J. Kossakowski and J. Stefańska. 2010 Synthesis and microbiological activity of thiourea derivatives of 4-azatricyclo[5.2.2.0(2,6)] undec-8-ene-3,5-dione. Arch. Pharm. Res. 33: 47-54.

Suresha G.P., R. Suhas, W. Kapfo and D.C. Gowda. 2011. Urea/ thiourea derivatives of quinazolinone-lysine conjugates: synthesis and structure-activity relationships of a new series of antimicrobials. Eur. J. Med. Chem. 46: 2530-2540.

Vega-Pérez J.M., I. Periñán, M. Argandoña, M. Vega-Holm, C. Palo-Nieto, E. Burgos-Morón, M. López-Lázaro, C. Vargas, J.J. Nieto and F. Iglesias-Guerra. 2012. Isoprenyl-thiourea and urea derivatives as new farnesyl diphosphate analogues: synthesis and in vitro antimicrobial and cytotoxic activities. Eur. J. Med. Chem. 58: 591-612. 